\title{
Influence of various miotics on cataract formation
}

\author{
S. V. ABRAHAM AND J. J. TELLER \\ Los Angeles, California, U.S.A.
}

The literature suggests that the use of miotics locally causes an increase in the size of the vascular bed of the iris and ciliary body through increased congestion (Seidel, I920; Goldmann, I95I ; Scholz, I946; Leopold and Comroe, I946; Hodgson, I 955). Hyperaemia is a known effect of all miotics. All anticholinesterase agents produce vasodilatation of the ciliary body and conjunctiva. Metabolic changes in the lens due to the use of miotics have also been reported (Müller, Kleifeld, Hockwin, and Dardenne, 1956).

As the miosis is produced, a ciliary muscle spasm is accompanied by an increase in the blood supply and in the protein content of the aqueous humour.

Iris cysts (seen in the pupillary area) have been reported after the use of most miotics, such as pilocarpine, phospholine, fluoropryl, and eserine (Vogt, I923; Abraham, 1954).

The prolonged use of miotics tends to produce a low-grade uveitis. In acute glaucoma there is a marked increase in the vascular bed. The existence of this basic hyperaemia is emphasized by the reactions which follow glaucoma surgery in such cases and the decreased reactions which follow the omission of miotics for an interval before such surgery (Abraham, I959).

Miotics may, at times, produce an increase in the intraocular pressure (Posner, 1955)even an acute glaucoma (Butler, 1952). Iritis and detachment of the retina have been reported by Leopold (1966) and Lemcke and Pischel (1966).

A small series of 45 cases of chronic open-angle glaucoma followed by one of us (S.V.A.) showed this tendency to increased intraocular pressure. In these 45 cases the glaucoma could not be controlled by strong miotic therapy alone or in combination with I or 2 per cent. epinephrine three or four times daily. The miotics used were either pilocarpine 6 per cent., phospholine $\frac{1}{16}, \frac{1}{8}$, or $\frac{1}{4}$ per cent., or Humorsol 0.25 or 0.125 per cent. The tension fell to normal in $\mathbf{2 8}$ of the 45 cases, and was reduced in another eleven cases, when the local therapy was discontinued. The pupils remained miotic as before in ten out of the 45 cases for the 2 months of observation, and the tension was under control during the observation period. In the remainder the pupil was noted to be increasing in size 2 to 8 weeks after discontinuing the local therapy; at the same time the tension rose, but 2 per cent. pilocarpine controlled this rise, where the stronger miotic had failed to do so earlier. The pupils were never observed to be over $3 \mathrm{~mm}$. in diameter when the miotics were discontinued.

These observations tend to support the idea that miotics have a dual action-on the one hand therapeutically beneficial in glaucoma and on the other hand counteracting this benefit by their effect on the vascular bed and on the permeability of the vessels involved. Amid the general enthusiasm for the benefits of miotics, their opposite effects have not been fully considered. 


\section{Present investigations}

This paper reports observations on 636 eyes, 370 in persons aged from 40 to 64 years (average $5^{2}$ ) and 266 in persons aged from 65 to 88 years (average 70*2). The lens changes seen before miotic therapy was given are shown in Table I; 7 per cent. of the younger eyes and $5 \mathrm{I} \cdot 5$ per cent. of the older eyes showed such changes.

Table I Cortical (non-nuclear) lens changes in 636 eyes ( 300 without glaucoma) before miotic therapy was started, by age group

\begin{tabular}{|c|c|c|c|c|}
\hline \multicolumn{2}{|c|}{ Age (yrs) } & \multirow{2}{*}{$\begin{array}{l}\text { No. of } \\
\text { eyes }\end{array}$} & \multicolumn{2}{|c|}{$\begin{array}{l}\text { Lens changes } \\
\text { before miotics }\end{array}$} \\
\hline Group & Average & & No. & Per cent. \\
\hline $\begin{array}{l}40-64 \\
65-88\end{array}$ & $\begin{array}{l}52 \cdot 0 \\
70 \cdot 2\end{array}$ & $\begin{array}{l}370 \\
266\end{array}$ & $\begin{array}{r}26 \\
137\end{array}$ & $\begin{array}{r}7 \cdot 0 \\
51 \cdot 5\end{array}$ \\
\hline Total & $61 \cdot 4$ & 636 & 163 & $25 \cdot 6$ \\
\hline
\end{tabular}

\section{UNTREATED EYES}

Of the total of $6{ }_{3} 6$ eyes, 300 were non-glaucomatous and these received no miotic therapy. They were all re-examined at the end of the study period of 2.9 years, when the percentage of lens changes had increased slightly in both the younger and older groups (Table II).

Table II Cortical (non-nuclear) lens changes in the 300 eyes without glaucoma which did not receive miotics, at beginning and end of the observation period, by age group

\begin{tabular}{|c|c|c|c|c|c|}
\hline \multirow{2}{*}{ Examination } & \multicolumn{2}{|c|}{ Age (yrs) } & \multirow{2}{*}{$\begin{array}{l}\text { No. of } \\
\text { eyes }\end{array}$} & \multicolumn{2}{|c|}{ Lens changes } \\
\hline & Group & Average & & No. & Per cent. \\
\hline $\begin{array}{l}\text { First } \\
\text { Second (after } 2 \cdot 9 \text { yrs) }\end{array}$ & $\begin{array}{l}40-64 \\
40-64\end{array}$ & $\begin{array}{l}53 \cdot 1 \\
56 \cdot 0\end{array}$ & $\begin{array}{l}150 \\
150\end{array}$ & $\begin{array}{l}12 \\
17\end{array}$ & $\begin{array}{r}8 \cdot 0 \\
11 \cdot 3\end{array}$ \\
\hline $\begin{array}{l}\text { First } \\
\text { Second (after } 2 \cdot 9 \text { yrs) }\end{array}$ & $\begin{array}{l}65-88 \\
65-88 \\
\end{array}$ & $\begin{array}{l}69 \cdot 2 \\
72 \cdot 1\end{array}$ & $\begin{array}{l}150 \\
150\end{array}$ & $\begin{array}{l}69 \\
81\end{array}$ & $\begin{array}{l}46 \cdot 0 \\
54 \cdot 0\end{array}$ \\
\hline $\begin{array}{l}\text { First } \\
\text { Second }\end{array}$ & $\begin{array}{l}\text { All age } \\
\text { All age }\end{array}$ & & $\begin{array}{l}300 \\
300\end{array}$ & $\begin{array}{l}81 \\
98\end{array}$ & $\begin{array}{l}27 \cdot 0 \\
32 \cdot 7\end{array}$ \\
\hline
\end{tabular}

\section{TREATED EYES}

In the 336 glaucomatous eyes, various miotics were used in 544 trials as set out in Table III (below).

Patients were not brought into the study series if carbonic anhydrase inhibitors, such as Diamox, were required when the ocular tension could not be controlled by miotics alone, and also if systemic steroids were required for some general condition such as arthritis.

No drugs were used in the cases studied except medication for diabetes.* Steroids might, however, be used locally for ocular inflammation provided that the period involved was less than 2 weeks.

*The untreated (non-glaucomatous) patients under 65 years of age included four diabetics and those aged 65 years or over included six. The treated (glaucomatous) patients under 65 years of age included five diabetics and those aged 65 years or over included seven, so that the proportions of diabetics were roughly equal in all groups. 


\section{Dosage}

\section{Pilocarpine}

Usually 2 per cent. solution used three or four times daily with 2 per cent. ointment on retiring. Very rarely a 4 per cent. solution was used.

\section{Phospholine}

Solution varying from $\frac{1}{16}$ to $\frac{1}{4}$ per cent. used most frequently once a day on retiring, and also every other night in some cases.

It was never used twice daily except in aphakic cases, but these were excluded from the study.

Phospholine with Phenylephrine (Tables III and IV, below)

Solution usually $\frac{1}{8}$ or $\frac{1}{16}$ per cent. combined with phenylephrine 2.5 per cent. once daily.

\section{Observations}

In none of the treated cases included in this study was maximum dilation of the pupil deliberately obtained. Such dilation in an elderly patient under miotics for a considerable period would be difficult and requires considerably more cooperation by the patient. In this study a $5 \mathrm{~mm}$. pupil was usually sufficient to demonstrate anterior and posterior cortical changes. This, coupled with visual changes, usually helped to reveal most of the lens changes except those in the equatorial area, which very rarely occur alone. Most anterior and posterior cortical changes could be seen with pupils even as small as $3 \mathrm{~mm}$.

Since posterior cortical lens changes may frequently be noted in high myopia, it is of value to point out that the treated patients aged 65 years or over included only six cases of myopia of $6 \cdot 00$ dioptres or more.

\section{Lens changes included in assessment}

Nuclear lens changes may develop very gradually and may reflect only the "normal" ageing process. Visual disturbance is least troublesome in these cases and fundus examination can be carried out with relative ease even when considerable sclerosis is observed with the slit lamp. Until vision is definitely disturbed by the sclerotic process (in the absence of posterior cortical changes), one should hesitate to call the "normal" sclerosis a cataract.

For this reason, and since the earliest and major changes in the lens are noted to be cortical rather than nuclear when a toxic reaction is produced, the present observations are limited to cortical (non-nuclear) changes. Increased visibility of the adult nucleus was not considered to be a lens change and this change alone did not explain any decrease in vision that was observed.

Minute flecks, congenital or infantile lens opacities, or changes due to long-past inflammations or trauma were ignored in all cases, and these, when present, did not change during the observation period.

\section{Effects of age}

The data in Table I suggest that one must consider not only the average age of the whole group but also the range covered. In patients of 65 years or over one may expect cortical (non-nuclear) lens changes in over $5^{\circ}$ per cent. of the eyes examined, while in those under 
65 years of age one may expect considerably fewer significant positive lens findings. Naturally, the younger the patient, the less likely are significant positive changes to be found.

\section{Results}

Table III shows the findings in 336 eyes treated with various miotics. The total is given as 544 trials as some eyes were treated differently at different times. Thus $37 \cdot 7$ per cent. showed new or progressive cortical lens changes after miotic therapy, 15.6 per cent. of those under 65 years of age, and $6 \mathrm{I} \cdot 8$ per cent. of those over 65 years of age.

Table III suggests that no one miotic drug affects the lens more than another in the younger age group, but Phospholine seems to produce a greater percentage of changes in the older age group (and in a shorter time).

Table III Cortical (non-nuclear) lens changes in 336 glaucomatous eyes after the use of miotics, in 544 trials

Results analysed by age group, and by miotic used

\begin{tabular}{|c|c|c|c|c|c|c|}
\hline \multirow{2}{*}{ Miotic } & \multirow{2}{*}{$\begin{array}{l}\text { Age } \\
\text { group } \\
\text { (yrs) }\end{array}$} & \multirow{2}{*}{$\begin{array}{l}\text { Mean } \\
\text { observation } \\
\text { period (yrs) }\end{array}$} & \multirow{2}{*}{$\begin{array}{l}\text { Average } \\
\text { age } \\
\text { (yrs) }\end{array}$} & \multirow{2}{*}{$\begin{array}{l}\text { No. of } \\
\text { trials }\end{array}$} & \multicolumn{2}{|c|}{ Lens changes } \\
\hline & & & & & No. & Per cent. \\
\hline Pilocarpine only & $\begin{array}{l}<65 \\
>65\end{array}$ & $\begin{array}{l}3 \cdot 9 \\
2 \cdot 3\end{array}$ & $\begin{array}{l}5 I \cdot I \\
68 \cdot 6\end{array}$ & $\begin{array}{r}196 \\
90\end{array}$ & $\begin{array}{l}30 \\
56\end{array}$ & $\begin{array}{l}15 \cdot 3 \\
62 \cdot 2\end{array}$ \\
\hline Phospholine & $\begin{array}{l}<65 \\
>65\end{array}$ & $\begin{array}{l}2 \cdot 1 \\
0 \cdot 9\end{array}$ & $\begin{array}{l}5 I \cdot 2 \\
69 \cdot 3\end{array}$ & $\begin{array}{l}5^{6} \\
4^{8}\end{array}$ & $\begin{array}{r}9 \\
36\end{array}$ & $\begin{array}{l}16 \cdot 1 \\
75 \cdot 0\end{array}$ \\
\hline E-B ${ }_{3} *$ & $\begin{array}{l}<65 \\
>65\end{array}$ & $\begin{array}{l}I \cdot 8 \\
I \cdot 4\end{array}$ & $\begin{array}{l}50 \cdot 4 \\
72 \cdot 1\end{array}$ & $\begin{array}{l}56 \\
98\end{array}$ & $\begin{array}{l}5^{6} \\
54\end{array}$ & $\begin{array}{l}16 \cdot 1 \\
55 \cdot I\end{array}$ \\
\hline \multirow[t]{2}{*}{$\begin{array}{l}\text { Total } \\
\text { Trials }\end{array}$} & $\begin{array}{l}<65 \\
>65\end{array}$ & $\begin{array}{l}3 \cdot 1 \\
1 \cdot 4\end{array}$ & $\begin{array}{l}5^{1 \cdot 0} \\
70 \cdot 2\end{array}$ & $\begin{array}{l}308 \\
236\end{array}$ & $\begin{array}{r}48 \\
146\end{array}$ & $\begin{array}{l}15 \cdot 6 \\
6 I \cdot 8\end{array}$ \\
\hline & All ages & $2 \cdot 4$ & $59 \cdot 3$ & 544 & I94 & $35 \cdot 7$ \\
\hline
\end{tabular}

* Solution of phospholine iodide $\frac{1}{8}$ per cent. and phenylephrine hydrochloride $2 \cdot 5$ per cent., available from Ayerst Laboratories, New York, for investigational use only

286 eyes were treated with pilocarpine only (Table III). In other eyes, the Phospholine or pilocarpine therapy was followed by another miotic. In 54 eyes Phospholine was used after pilocarpine had been used for many months or years. In 44 eyes, the Echophenyline- $\mathrm{B}_{3}$ formulation* was used after pilocarpine had been used, and in 48 eyes E-B 3 was substituted after pilocarpine and phospholine had both been used in turn. Thus, in a total of 104 eyes (or trials) Phospholine iodide was used, and in I54 eyes (or trials) E-B 3 (see Table III).

There were 50 eyes treated primarily with Phospholine and 62 eyes treated primarily

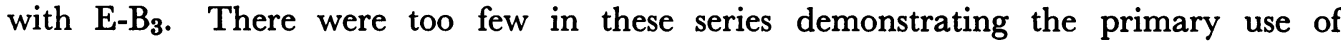
Phospholine and E-B $\mathrm{B}_{3}$ for them to be of particular value by themselves, but they are included in Table IV, and the findings are seen to be in keeping with the total data collected. In the 26 younger eyes (averaging $5^{\mathrm{I}} \cdot 3$ years of age) treated primarily with Phospholine iodide, the positive findings rose from $7 \cdot 6$ to 15.3 per cent. in an average observation period of $1 \cdot 5$ years, and in the 24 older eyes (averaging $71 \cdot 1$ years of age) so treated the positive findings rose from $5^{8 \cdot 3}$ to $75^{\circ} \mathrm{O}$ per cent. in an average observation period of only $0 \cdot 8$ years.

Table IV shows a comparison of cortical and subcapsular lens changes noted in eyes while using Phospholine and Echophenyline- $\mathrm{B}_{\mathbf{3}}$.

*A solution containing Phospholine iodide $\frac{1}{8}$ per cent. and phenylephrine hydrochloride 2.5 per cent. Available only for investigational use from Ayerst Laboratories, New York. 
Table IV Lens changes in patients above and below 65 years of age with various treatment schedules (other than Pilocarpine only)

\begin{tabular}{|c|c|c|c|c|c|c|c|}
\hline \multirow{4}{*}{\multicolumn{2}{|c|}{ Treatment schedule }} & \multicolumn{6}{|c|}{ Age (yrs) } \\
\hline & & \multicolumn{3}{|l|}{$<65$} & \multicolumn{2}{|l|}{$>65$} & \multirow{3}{*}{ 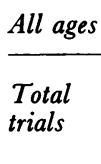 } \\
\hline & & \multirow{2}{*}{$\begin{array}{l}\text { No. of } \\
\text { trials }\end{array}$} & \multicolumn{2}{|c|}{ Lens changes } & \multirow{2}{*}{$\begin{array}{l}\text { No. of } \\
\text { trials }\end{array}$} & Lens changes & \\
\hline & & & No & Per cent. & & No. Per cent. & \\
\hline & $\begin{array}{l}\text { Phospholine after } \\
\text { Pilocarpine }\end{array}$ & 30 & 5 & $16 \cdot 6$ & 24 & $1875^{\circ} 0$ & 54 \\
\hline (2) & $\begin{array}{l}\text { Phospholine as } \\
\text { primary agent }\end{array}$ & 26 & 4 & $15 \cdot 3$ & 24 & $1875^{\circ} 0$ & 50 \\
\hline (3) & E-B ${ }_{3}$ after Pilocarpine & 18 & 3 & $16 \cdot 6$ & 26 & $14 \quad 53 \cdot 8$ & 44 \\
\hline$(4)$ & E- $B_{3}$ as primary agent & 18 & 3 & $16 \cdot 6$ & 44 & $23 \quad 52 \cdot 3$ & 62 \\
\hline (5) & $\begin{array}{l}\text { E-B } 3 \text { after Pilocarpine } \\
\text { followed by Phospholine }\end{array}$ & 20 & 3 & $15 \cdot 0$ & 28 & $1760 \cdot 7$ & $4^{8}$ \\
\hline
\end{tabular}

The following exceptions to the averages were observed:

\section{(I) Phospholine}

In the control group of I 50 UNTREATED older eyes (over 65 years of age), the lens changes noted after an average of $2 \cdot 9$ years increased from 46 to 54 per cent. In the 48 TREATED older eyes, 75 per cent. showed new or progressive cortical (non-nuclear) lens changes compared with 58.3 per cent. before therapy (observation 0.9 years) (Table III).

The difference between these two comparisons may not be significant because of the smaller number of Phospholine-treated cases, but it does suggest a possible tendency.

(2) $\quad E-B_{3}$

The eyes treated with Phospholine combined with a decongestant (Phenylephrine) showed a smaller percentage of positive cortical (non-nuclear) lens changes than the average for the older group ( $6 \mathrm{I} \cdot 8$ per cent.). Of 98 older eyes treated with $\mathrm{E}-\mathrm{B}_{3}, 54$ ( $55^{\cdot \mathrm{I}}$ per cent.) showed significant cortical (non-nuclear) lens changes (Table III).

\section{Discussion}

In the literature it has been noted that the use of the stronger anticholinesterases is more likely to produce changes. Both Axelsson and Holmberg (I g66) and deRoetth (I966a, b) used these stronger drugs more than once daily even though their effectiveness as miotics usually persists even 24 hours after use. This may well be one of the reasons why Axelsson and Holmberg (1966) found six cases of tremulous lenses in 78 cases.

Leopold (1966) has pointed out that Phospholine produced no lens changes, no cysts, and no synechiae in rabbits. Our own work on rabbits conducted over a 3-month period has given similar negative findings (Abraham, unpublished data).

One cannot easily accept statements concerning the harmful effects of one miotic as compared to another, if differences in duration of effectiveness and intensity of local response of the vascular bed are not considered. If one accepts the principle of "dual action" of miotics, as described earlier in this article, a greater reaction to stronger than to weaker solutions is not surprising. 
The use of vasoconstrictors, such as epinephrine or phenylephrine, may be of benefit when used either alone or before the miotics (Blanton and Pollack, I966) or in combination with the miotics. A stronger miotic has advantages over a weaker one in that it may be used less frequently and may give better control when used initially.

In those under 65 years of age it would seem that miotics may be used judiciously without fear of producing lens changes-the younger the patient the less the risk.

Lens changes may be expected in persons aged 65 years or over, and may be due as much to age as to the use of miotics.

Visual changes may be due to increased convexity of the newer lens fibres, to increased fluid content of the lens fibres, or to opacification of the lens. Because the posterior pole of the lens coincides to a large degree with the crossing of the light rays on their way to the retina, lens changes in the posterior polar area are those most likely to impair vision. Careful slit-lamp observations must be made to check these changes at an early stage.

Repeated investigations, including refraction, plotting the visual fields, tension studies, and slit-lamp examination (after temporary discontinuation of the miotic), can help the ophthalmologist to assess the various effects of miotics, both beneficial and harmful.

\section{Conclusions}

Age is a factor to be considered in a study of the effect of miotics on the lens.

A realistic approach to the therapy of glaucoma with miotics should consider their dual action. There seems to be some justification for the suspicion that miotics are not entirely harmless.

The stronger miotics, such as the anticholinesterases, are more likely to cause lens changes than the cholinergic agents.

Further study is necessary to clarify the role of the decongestants in the therapy of glaucoma. The possibility is suggested that they are of benefit when used with a miotic.

\section{References}

abraham, s. v. (1954) Amer. F. Ophthal., 37, 327

${ }_{1488}$ (1959) "VIII Concilium Ophthalmologicum, I958, Belgica Acta", vol. 2, pp. I473-
AXELsson, U., and HOLmberg, Å. (I966) Acta ophthal. (Kbh.), 44, 42 I

Blanton, F. M., and POllaGK, I. P. (1966) Arch. Ophthal. (Chicago), 75, 763

BUTLER, W. E. (1952) Amer. F. Ophthal., 35, 1031

De roetth, A., JR. (1966a) J. Amer. med. Ass., 195, 664

- (1966b) Amer. F. Ophthal., 62, 619

goldmann, H. (I951) Docum. ophthal. (Den Haag), 5-6, 278

hodgson, т. H. (1955) In "Glaucoma: A Symposium", ed. S. Duke-Elder, p. 273. Blackwell

Scientific Publications, Oxford

LeMCKe, H. н., and PISGHel, D. K. (1966) Trans. Pacif. Cst oto-ophthal. Soc., 47, 157

LEOPOLD, I. H. (1966) Amer. J. Ophthal., 62, 77 I and comroe, J. H. (1946) Arch. Ophthal. (Chicago), 36, 17

MÜLLER, H. K., KLEIFELD, O., HOCKWIN, O., and DARDENNE, U. (1956) Ber. dtsch. ophthal. Ges., 6o, I I 5 Posner, A. (1955) Eye, Ear, Nose, Thr. Monthly, 34, 520

scholz, к. о. (1946) J. Pharm. exp. Ther., 88, 23

SEIDEL, E. (1920) v. Graefes Arch. Ophthal., 102, I89

vOGT, A. (1923) Ibid., 111, 91 